\title{
OVERWIEW ABOUT THE VISION, MISSION, GOALS AND VALUES OF NONGOVERNMENTAL ORGANIZATIONS
}

\author{
Nicoleta Ciucescu \\ "Vasile Alecsandri” University of Bacau \\ ciucnico@yahoo.com
}

\begin{abstract}
The herein article aims to address several specific aspects regarding the definition of nongovernmental organizations, their vision and mission. Also the setting of goals and the presentation of the values of these types of organizations will be presented using a comparative study of literature as a research method. The fields in which nongovernmental organizations operate are very diverse, as are the needs of the community, respectively: education, science, research, culture, social protection, minorities, human rights, environmental protection, child protection, etc. The mission of the organization lies in the ample mentioning of the fundamental goals and of the view regarding the evolution and progress of the organization's activities, from which the activity field, the market served, as well as the differentiation from other similar organizations, result. Nongovernmental organizations are characterized by a great mobility in the manner of action. Their operation is dependent on the correct identification of the needs of the community and on their ability to attract the funds required to cover them. A nongovernmental organization can play an essential role within the society by identifying certain courses of action, omitted by the public authorities. They can approach the identified niches by using their own organizational skills and human resources or they can offer assistance to the authorities.
\end{abstract}

Keywords

vision; goals; community; public utility; nonprofit

\section{JEL Classification}

M29

\section{Introduction}

The article presents non-governmental organisations in terms of defining their vision and mission of presenting them, and the way of setting objectives and values that ensure their proper functioning. The research method used to achieve those objectives consists of a comparative study of literature.

"Nongovernmental organisations" represent the Romanian semantic and syntactic unit by which the positioning of these organisations is realized, them being distinct from the government and from private organisations focused on obtaining profits, and have the legal attribute of being legally liable for the consequences of the application of the decisions taken on their own behalf.

Vlăsceanu Mihaela (1996, p.98) asserts that non-profit organizations are private in form and public through their finalities, offering communities, for consumption, collective goods or products with public utility (health, educational, cultural, protective services etc.), are guided by the principle of profit non-distributivity between the ones who own them or run them, are independent of the governmental institutions and apparatus, having at their disposal self-governing mechanisms similar to the ones of 
profit organizations, involving the participation of members also in the form of volunteering in a variable, but nonetheless inevitable, proportion.

In the category of nongovernmental organizations of public interest or of public utility, those organizations are integrated that by their group, target and activity type, demonstrate a certain vocation for the good of the community. They conduct public interest programs from which the entire community or a large number of its members benefit.

\section{Aspects regarding nongovernmental organizations}

Nongovernmental organizations don't have the aim to obtain profit or to access political power, representing those structures, respectively informal groups or natural persons who conduct their activity independently of any public authority.

The characteristics of nongovernmental organizations belong on one hand to the public sector, and on the other hand also to the private sector, in the sense that they present the flexibility specific for the private sector and have fewer constraints in activity compared to the public sector. If we consider the set goals, as well as all means used to reach them, respectively the public utility status of nongovernmental organizations, then they are closer to the public sector, than to the private one. This is precisely why nongovernmental organizations represent the ideal partners within the public-private type partnerships.

Currently, researchers and practitioners worldwide, as well as those from Romania have accepted and used the classification developed by Johns Hopkins University in USA ICNPO - International Classification for Non-Profit Organizations, that divides organizations into 12 major activity groups, namely: culture and recreation, education and research, health, social services, environment, human development and habitat, political and legal lobby, philanthropic and voluntary intermediaries, international, religion, professional and business organizations and other groups that aren't classified.

\section{Vision}

The vision represents an ideal state, respectively the nongovernmental organization's long-term aspiration to the future, for over 5 years, which configures a possible and desirable development of the respective organization. The vision is expressed concisely and in a manner easy to understand by the staff and by the public, through the medium of a short sentence, and the wording of this sentence is not required to contain quantifiable elements.

In my opinion, the vision must be shared and accepted by all members of the organization, must ensure its unity by choosing a common goal, and must offer all members the possibility to be able to identify their interests. This is done through a declaration of commitment. Although often between the vision of the organization's founders and its subsequent evolution a series of deviations occur, the definition of the organization's vision actually represents a prerequisite for its existence and development. Moreover, the mission and the goals of the nongovernmental organization must be established.

\section{Mission}

The mission of an organization expresses (Nica Panaite and Iftimescu Aurelian, 2002) the raison of that organization in relation to its main partners, the clients. Through the 
mission also the specificity of the basic conducted activities is specified and the direction in which they are heading in the future is suggested, sometimes appealing to emotions and feelings.

The mission of an organization mirrors the vision of the organization regarding its statute (its credo) and what it aims to realize for a given target, for a longer period and namely the desired period of existence of the organization. Upon its establishment, one always starts from an unmet need of the community, which can constitute the aim of the organization, and so the company's field of existence. (Străinescu, I., Ardelean B., 2007, p.23)

In my opinion, the mission expresses the aim for which the organization was created and offers an overview regarding what the respective organization is and what it wants to do for the society.

A properly formulated mission must answer to the following questions:

- Who is the organization?

- What does it do?

- Where is it going?

The mission is characterized by the fact that it refers to the orientation, perspectives and attitudes of the organization and does not represent an enunciation of certain quantifiable elements to be achieved.

Mihaela Vlăsceanu (1996) emphasizes the first problem faced by a non-profit organization, it refers to the identification and definition of a clear and precise mission, and this implies not only the delimitation of the aims for which the organization was created, but also their formulation in a such manner that the possibility of constant assessment of the obtained performances exists.

The wording of the non-profit organization's mission can greatly influence its launch, since the mission communicates the essence of the organization's message. Consequently, it is recommended that the message of the mission is shortly worded and of a nature to provide a clear overview of the type of activities that it will conduct in the future, without going into details.

It is preferable that the mission statement does not exceed one phrase, but that it includes at least the following ideas:

- organization's vision (the place where it aims to go, when the mission is completed),

- fundamental aim (what precisely it wants to obtain, when the mission is completed), what its philosophy reflects,

- values promoted (the principles that guide the members of the organization in achieving the basic aim).

The correct wording of the organization's mission allows the concomitant realization of several of its roles:

- ensures the consensus within the organization, on the goals pursued;

- provides a foundation for motivating the use of the resources in a certain way;

- develops a unitary view for the allotment of all resources;

- contributes to the establishment of a harmonious climate within the organization;

- considers the mission a landmark for those "stakeholders" who can identify themselves with the aims and courses of action of the organization and drives away those who are unable to do so;

- formulates the aims, the general goals of the organization and facilitates their translation into objectives related to efforts, effects, efficiency, objectives which can be easily evaluated and controlled. 
Not only the wording of the mission is important, but also its communication.

In this context, in order for the best possible communication of the mission to be ensured, it must:

- crystallize the views of top managers about the long-term directing of the company;

- specify the help which the company's administration will grant middle level managers in order for them to go on the right track;

- communicate the organizational goal and the fact that the employees have the ability to cause a change in their work;

- show how the organization prepares for its future orientation (Nica Panaite and Iftimescu Aurelian, 2002, p.97-98).

The mission statement is made explicitly, in writing.

Moldoveanu George (2005) covers in his paper "Organizational analysis and behaviour" a sub-chapter entitled "Mission and stakeholders".

The stakeholders are the ones who have "claims" against the organization, are its supporting "pillars". The stakeholders can be structured in two groups:

a) The internal group, materialized in employees, including the members of the board of directors and managers on functions and activities, who represent the interest of the shareholders in all processes of the organization.

b) The external group, formed of individuals and groups which are affected by the organization's actions, such as clients, consumers, suppliers, governmental structural forms, union missions, competitors, local communities, public elements in general.

On the other hand, each nongovernmental organization must present its main goals, namely:

- Goals of action - that establish specific, quantifiable objectives for the organization;

- Goals of imagine - through which the organization makes itself known to the beneficiaries of the market segment for which it wants to work and, respectively, to sponsors it wants to involve, mass-media, general public etc.

The vision and aim of a nongovernmental organization do not remain defined once and for all, they can suffer changes, adaptations depending on the existing sociocultural context.

For example we will present the vision, mission and aim for a foundation and an association. Vision, mission and aim of the Civil Society Development Foundation are:

The vision of the Foundation for the Development of the Civil Society is one of a strong and influent civil society, with responsible, involved citizens, who promote their interests and values for the good of the communities.

The mission of FDSC is to develop the ability of civil society organizations to act efficiently in the interest of communities.

$>$ Aim: The Foundation for the Development of the Civil Society is an "organization for organizations", that considers that the development of the nongovernmental sector is in itself an indicator for the state of the community in which the citizens live.

In the Association "There is a chance," the vision, the mission and aim are:

$>$ The vision Association "There is a chance": To build a community where everyone has their rights respected.

$>$ Our mission "There is a chance" is to improve the quality of life of community members in need, at risk of marginalization and social exclusion. 
$>$ Aim: To develop an alternative offerings / solutions for promoting the rights and capacities of people at risk of marginalization and social exclusion in view of a better life.

\section{Aims}

The objectives derive from the vision and mission undertaken by each non-profit organization. The objectives or targets are the endpoints towards which the global or separate activities of the organization are aimed, so that the objectives can be general or specific for different activities / groups of activities. The fundamental objectives constitute the first operational component of the strategy which is formulated starting from the mission and represent those objectives that refer to it as a whole, to the major components of the organization's activities and regard long horizons, usually $3-5$ years.

Depending on their content, the fundamental objectives can be economic and social, and depending on the manner of expression, quantifiable and non-quantifiable.

The economic objectives synthesize and commeasures the long term goals considered by the most important stakeholders (earnings per share, share value, profit, profit rate, turnover, work productivity).

The social objectives, which are more rarely incorporated in the strategies of organizations, usually refer to the control of pollution, salaries and working conditions of the employees, cooperation with the authorities, customer satisfaction through the quality, reliability, maintainability and price of the offered products and services, and so on.

Quantifiable objectives enounce the most important existence causes of the organization, while the non-quantifiable objectives reflect concerns for its social responsibilities. Neglecting these social responsibilities can have as consequence a series of aspects related to the decrease in the motivation and loyalty of its own employees, which can lead to the deterioration of the organization's image. For these reasons, any organization must ensure a constant balance between the economic and social objectives.

In my opinion, the strategic objectives of the organization are established in all fields, on which not only the survival, but also the success of the organization depend, being indispensable for all hierarchical levels of management. The strategic objectives must be established within an organization so that they are possible to achieve and that they can condition the efficacy of their use in the management process. They should not be set only in terms of "what would be good", but have to be able to mobilize the entire organization's potential, even if they refer to external conditions of the organization (objectives related to its position in relation to the competitors or to its aspirations for a certain place within the area in which it conducts its activity) or to internal conditions (objectives related to the desired level of performance).

Great attention should be given when formulating objectives. If the objectives are formulated properly, than they:

1. will be able to be transformed into specific actions;

2. will provide the direction to take, representing the starting point for more detailed and more specific objectives at the inferior hierarchical levels of the organization;

3. will set long-term priorities;

4. will facilitate the managerial control, because they serve as performance standards in relation to which the performance of the entire organization can be assessed.

Panaite Nica and Aurelian Iftimescu provide a detailed presentation on setting targets (2002, p.100-103). 
The manner in which the objectives of various organizational entities within a company are established (business units, divisions, departments, workplaces) conditions to a large extent the efficacy of their use in the management process.

Traditionally, the objectives are established in cascade, meaning that they are imposed from top to bottom, starting from the strategic objectives of the entire organization and going, by breakdown on different component sub-units, up to the workplaces at the bottom of the hierarchal pyramid. Of course, proceeding in this manner ensures coherence and convergence to different objectives within the organization. Their realism and capacity to mobilize can be however seriously affected, especially in a dynamic and complex environment, as the one many contemporary organizations must cope with.

An effective alternative to the traditional manner of setting goals can be constituted by the management through objectives. This is a planning and control system designed and implemented for the first time in the early '50s, by Peter Drucker, known management professor and consultant.

Essentially, the management through objectives is a method to convert the general objectives of the organization into specific objectives for the organization's sub-units and the individuals that compose it, by negotiation between the manager and subordinates, and to evaluate individuals depending on their actual performances and the objectives thus established. For the managers of different sub-units within the organization, individual objectives greatly overlap the objectives of the managed subunits.

The process of management through objectives comprises three major stages:

- $\quad$ establishing the objectives and actions required for their accomplishment;

- $\quad$ implementing the provided actions and self-control of achieving the objectives;

- $\quad$ periodical examination by the superiors of individual performances and assessment of the subordinates.

The increasing use of management through objectives is determined by its advantages. Amongst the most important we mention: the increase of the realism of the organization's objectives and of its components, the amplification of the employees' level of motivation, the development of a participative and responsible behaviour of the staff, the closer correlation of rewards (including salary rewards) with individual performances, improving the managers' use of the working hours, as a result of reducing the supervision and control activities.

The advantages of management through objectives are not however universal. In certain cases, the implementation of this system generates a high workload and a high volume of written documents. Other times, the system determines the focus of attention on a smaller number of objectives, particularly quantitative, neglecting the others. Therefore, management through objectives appears to be efficient especially when applied to managers or specialists in an organization, being likely to generate costs higher than the effects obtained for those with routine tasks.

\section{Values}

The values represent a sum of features that give value to things, facts, ideas, phenomena, being, in general, relatively different from one organization to another. Nongovernmental organizations are also relatively separated from other types of organizations by a system of own values which can be found in table 1 . 
Table1. Typical values of an NGO

\begin{tabular}{|l|l|}
\hline Responsibility & Learning \\
\hline Competitive differentiation & Openness \\
\hline Compassion & Partnership \\
\hline Diversity & Priority focus on the clients' needs \\
\hline Dynamism/innovation & Quality/excellence \\
\hline Efficiency & Respect \\
\hline Empowerment & Mutual development / self-support \\
\hline Equal opportunities / equity & Teamwork \\
\hline $\begin{array}{l}\text { Equal rights in reaching the } \\
\text { potential }\end{array}$ & Trust \\
\hline Inclusion & Valuing people \\
\hline Integrity & \\
Source: Courtney R, Strategic Management for Voluntary Nonprofit Organizations, London, New York: \\
Routledge, 2002, p.169
\end{tabular}

\section{Conclusions}

In areas where the market is not functional, and the government is not efficient, there is a third sector in which non-profit organizations conduct their activity. Although non-profit organizations can be defined as private organizations, they are distinct from the government and from private organizations focused on obtaining profit. Nongovernmental organizations differ from the ones focused on obtaining profit, because they tend to be determined by a specific mission, the property belongs to the organization and is not distributed between shareholders, as in the case of private companies.

In most countries of the world, as well as in Romania, nongovernmental organizations ordinarily operate as distinct legal persons, but they can also conduct their activity without having any legal personality, as informal groups, in which case the members bear the legal responsibility. For the smooth running of the activities of these organizations it is necessary that the vision, mission, objectives, as well as the values each of them promotes, irrespective of the area in which they conduct their activity, are established and known. The non-profit orientation determines the finding that the management applied in these organizations is a management conveniently adapted to the issues and specificity of the non-profit activity, whose characteristics would be: orientation towards efficiency (rationality), orientation towards objectives, orientation towards marketing.

\section{References}

Avram, E., Cooper, C. (2008), Psihologie organizaţional-managerială. Tendinţe actuale, Iaşi, Editura Polirom

Boboc, I. (2004), Managementul Organizaţiilor Non-Profit, Bucureşti, Editura Didactică şi Pedagogică

Bryson, J.M. (2002), Planificarea strategică pentru organizaţii publice şi nonprofit, Editura Arc, Bucureşti

Courtney, R. (2002), Strategic Management for Voluntary Nonprofit Organization, London, New York, Routledge 
Green, J. C., Griesinger, D. W.(1996), Board Performance and Organizational Effectiveness in Nonprofit Social Service Organizations, Nonprofit Management and Leaderships

Medina-Borja, A. Triantis, K. (2007), A conceptual framework to evaluate performance of nonprofit social service organizations, International Journal of Technology Management, vol. 37, no. 1-2

Mironescu R., Feraru A. (2012), Intellectual Capital as a Basic Resource for a New Organizational Behavior And Economic Development, Proceedings of the 4rd European Conference on Intellectual Capital, Arcada University of Applied Sciences, Helsinki, Finland, CD version ISBN: 978-1-908272-32-4, CD version ISSN: 2049-095X , Book version ISBK: 978-1-908272-31-7, Book Version ISSN: 2049-0933

Moldoveanu, G. (2005), Analiză şi comportament organizaţional, Bucureşti, Editura Economică

Nanus, B., Dobbs, S. (1999), Leader Who Makes a Difference. Essential Strategiesfor Meeting the Nonprofit Challenge., San Francisco, Jossey- Bass Publisher

Nica, P., Iftimescu, A. (2002), Management. Concepte şi aplicaţii, Iaşi, Editura Sedcom Libris

Nicolescu, O., Verboncu, I. (2007), Managementul organizaţiei, Bucureşti, Editura Economică

Nutt, P. C., Backoff, R. W. (1992), Strategic management of public and third sector organizations, San Fransisco: Jossey-Bass

Pettinger, R., Frith, R. (2008), Measuring Business and Managerial Performance. A practical guide, STC Ltd.

Popa, V. (2004), Strategii manageriale interorganizaţionale, Târgovişte, Editura

Bibliotheca

Porter, M. (1986), L'avantage concurrentiel, Paris, InterEdition

Popa, V. (2004), Strategii manageriale interorganizaţionale, Târgovişte, Editura Bibliotheca

Steven Ott, J. (2001), Understanding Nonprofit Organization, Colorado, Westview Press

Străinescu, I., Ardelean B. (2007), Managementul ONG, Bucureşti, Editura Didactică şi Pedagogică

Thomas, L. (2005), Capacity Building for local NGOs: A guidance manual for good practice, London, Catholic Institute for International Relations

Turcu, O., Ciucescu, N., Drob, C., Feraru, A., Mironescu, R., Simionescu, Gh., Stan, A. (2008), Management, Bacău, Editura Alma Mater

Verboncu, I. (2006), Management, eficiență și eficacitate, Management\&Marketing, The official journal of the Society for Business Excellence

Vlăsceanu, M. (1996), Sectorul non-profit. Contexte, organizare, conducere, Bucureşti, Editura Paideia

http://www.lumeaong.org/lista-director-ong/47-educatie-civica-responsabilitatesociala/257-fundatia-pentru-dezvoltarea-societatii-civile-bucuresti.html 